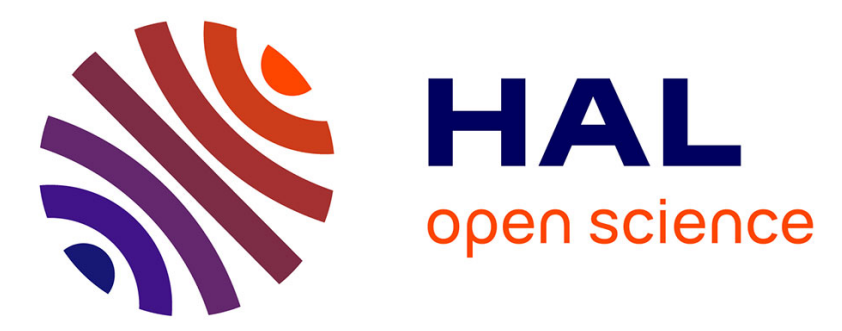

\title{
Overcoming the challenges associated with universal screening for Lynch syndrome in colorectal and endometrial cancer
}

\author{
Patrick R Benusiglio, Florence Coulet, Alexandra Lefebvre, Alex Duval, \\ Gregory Nuel
}

\section{To cite this version:}

Patrick R Benusiglio, Florence Coulet, Alexandra Lefebvre, Alex Duval, Gregory Nuel. Overcoming the challenges associated with universal screening for Lynch syndrome in colorectal and endometrial cancer. Genetics in Medicine, 2020, 22 (8), pp.1422-1423. 10.1038/s41436-020-0819-0 . hal-03212543

\section{HAL Id: hal-03212543 \\ https://hal.sorbonne-universite.fr/hal-03212543}

Submitted on 29 Apr 2021

HAL is a multi-disciplinary open access archive for the deposit and dissemination of scientific research documents, whether they are published or not. The documents may come from teaching and research institutions in France or abroad, or from public or private research centers.
L'archive ouverte pluridisciplinaire HAL, est destinée au dépôt et à la diffusion de documents scientifiques de niveau recherche, publiés ou non, émanant des établissements d'enseignement et de recherche français ou étrangers, des laboratoires publics ou privés. 


\section{Overcoming the Challenges Associated with Universal Screening for Lynch Syndrome in}

\section{Colorectal and Endometrial Cancer}

Patrick R. Benusiglio MD PhD ${ }^{1,2,3}$, Florence Coulet PharmD PhD ${ }^{2,3,4}$, Alexandra Lefebvre $\mathrm{MSc}^{2,5}$, Alex Duval MD PhD ${ }^{2}$, Gregory Nuel PhD ${ }^{5}$

1. Consultation d'Oncogénétique, Unité fonctionnelle d'Oncogénétique, Département de Génétique, DMU BioGeM, Groupe Hospitalier Pitié-Salpêtrière, AP-HP .Sorbonne Université, F-75013 Paris, France.

2. Sorbonne Université, INSERM, Unité Mixte de Recherche Scientifique 938 and SIRIC CURAMUS, Centre de Recherche Saint-Antoine, Equipe Instabilité des Microsatellites et Cancer, Equipe labellisée par la Ligue Nationale contre le Cancer, F-75012 Paris, France 3. Faculté de Médecine, Sorbonne Université, 91 Boulevard de l'Hôpital, F-75013 Paris, France

4. Laboratoire d'Oncogénétique, Unité fonctionnelle d'Oncogénétique, Département de Génétique, DMU BioGeM, Groupe Hospitalier Pitié-Salpêtrière, AP-HP .Sorbonne Université, F-75013 Paris, France

5. Laboratoire de Probabilités, Statistique et Modélisation, CNRS UMR 8001, Sorbonne Université, F-75005 Paris, France

\section{Corresponding author :}

PR Benusiglio

Email patrick.benusiglio@cantab.net, patrick.benusiglio@aphp.fr

Tel +33142177659

Twitter@PBenusiglio

ORCID: https://orcid.org/0000-0003-1003-199

Word count : 979 
Cancer genetics is moving towards widespread testing for genetic susceptibility to cancer, for example in breast and ovarian cancer patients. Regarding colorectal and endometrial cancer (CRC, EC), guidelines now recommend universal screening for Lynch syndrome (LS) ${ }^{1,2}$. Mismatch repair (MMR) protein immunohistochemistry (IHC) and/or microsatellite instability (MSI) testing, and if needed $M L H 1$ promoter hypermethylation (MLH1-hyper) analysis, are advocated in the tumor. Whenever there is an MMR-deficient (MMR-d) phenotype, i.e. MMR protein expression loss and/or MSI, and, for tumors with MLH1 loss, lack of $M L H 1$-hyper, somatic analyses should be followed by germline sequencing of the four MMR genes.

The actual implementation of universal screening at our institution highlighted the challenges associated with the practice. There are indeed potential difficulties at every stage of the process involving health professionals, patients and their families. We describe these challenges, report how they are changing the way we approach LS and explore novel strategies to overcome them.

Universal screening potentially triggers a cascade of tests and clinical appointments, for a final result that is negative or inconclusive for over $70 \%$ of cases. In a prospective IHCbased screening program for all CRC patients $(n=1290)$, only $16 / 58(27.5 \%)$ patients with MMR-d CRC (no MLH1-hyper) who proceeded to germline testing had LS ${ }^{3}$. For EC, the proportion was $29 \%$ following tumor-based triage in a systematic review ${ }^{4}$.

Additional analyses are warranted following negative germline testing, i.e. tumoral sequencing of the MMR genes in the search of double somatic pathogenic variants (PV). Indeed, biallelic somatic MMR inactivation accounts for about 50\% of MMR-d tumors without $M L H 1$-hyper and without germline PV, and rule out $\mathrm{LS}^{5}$. Tumoral sequencing however requires tumor tissue of sufficient quality and laboratories equipped to do it on a 
large scale. It thus may not be implementable everywhere on a routine basis. Furthermore, it still leaves half of cases unexplained.

These cases with a MMR-d phenotype, no MLH1-hyper, no germline or double somatic MMR PV have Lynch-like. Lynch-like suggests that there is a germline PV undetectable with current techniques, while we actually do not know what caused the MMR-d phenotype (it could as well have been undetected purely somatic PV). In this context, cases and relatives are often managed like bona fide LS with for example biennial colonoscopy. This is what the United Kingdom 2019 guidelines recommend ${ }^{6}$. As for the NCCN, it states that "no consensus has been reached as to whether these cases should be managed as LS or based on personal/family history" (https://www.nccn.org/professionals/physician_gls/pdf/genetics_colon.pdf). The only large study on Lynch-like suggested that CRC risk in families was about three times lower than in $\mathrm{LS}^{7}$. Caution should thus be exercised when dealing with a Lynch-like diagnosis. There are indeed potential negative consequences, should patients and their families be told they are probably at high risk of cancer and must therefore consider intensive multi-organ surveillance. Surveillance can lead to worry, false positives, overdiagnoses, and medical complications.

Additionally, germline testing is associated with the identification of variants of unknown significance (VUS). VUS generate uncertainty and anxiety among patients who know they might carry a PV, while medical providers have little to offer.

Mathematical models estimating LS probability using clinical data and basic family history have fallen out of fashion now that there is a consensus for universal screening. The logistic regression PREMM5 model was however good at identifying a subset of patients for LS screening. Its overall sensitivity was $89.4 \%$ at the $2.5 \%$ LS probability threshold $(97.4 \%$ and $92.6 \%$ for $M L H 1$ and $M S H 2$ respectively) in the original publication ${ }^{8}$. In a subsequent paper, the only missed LS diagnoses were in PMS2 PV carriers, a gene associated with cancer 
risks closer to the general population than classic $M L H 1 / M S H 2 / M S H 6 \mathrm{LS}^{3,9}$.

We believe mathematical models to be useful downstream universal screening to guide subsequent investigations and patient management. We are working on a novel integrative Mendelian model and expect it will be informative at every stage of the process. It will include patient and tumoral data such as age, IHC, MSI, MLH1-hyper, MMR somatic and germline sequencing results, and detailed family structure and history. A working version based on data from the literature will be improved by adding information extracted from a large series of patients from our multisite genetics clinic.

Its first aim will be to fit the management of Lynch-like cases to the LS probability (cancer screening, risk-reduction). Preliminary calculations suggest for example a 20-fold difference in probability between a case with MMR-d CRC at the age of 44 (MLH1-PMS2 loss, no MLH1-hyper, somatic MMR sequencing unavailable) and a second-degree relative with EC, and another case with sporadic MMR-d CRC at the age of 61 (MSH2-MSH6 loss, negative somatic MMR sequencing), neither of whom carrying an MMR PV. In addition, Lynch-like cases with a high LS probability will be ideal candidates for further investigations.

Along with tumor phenotype, functional assays, in silico analysis, and co-segregation, the LS probability will help reclassify MMR VUS as (likely) benign or pathogenic. It might complement co-segregation since LS probability can be calculated in every relative through its Mendelian approach.

We will finally test the thought-provoking hypothesis that a small subpopulation (5$10 \%$ ) of patients with MMR-d CRC or EC and no $M L H 1$-hyper do not need germline testing. We base our assumptions on a large study on universal screening. In a series of 3300 patients, MMR-d CRC cases diagnosed after the age of 65 and with no previous personal of family history of LS-related cancers never had LS ${ }^{10}$. A better selection of patients requiring genetic counseling and germline testing would save time and resources. 
In summary, while perfectly justified, the implementation of universal screening for LS also leads to inconclusive results, excessive surveillance, patient anxiety, and overstretching of existing resources. We advocate in this context novel approaches centered on the development of a prediction model for every stage of the testing process to guide subsequent investigations and patient management.

\section{Acknowledgments}

Patrick R. Benusiglio and Florence Coulet's teams are partly supported by the French Institut National du Cancer (INCa) via an annual, renewable grant. Alexandra Lefebvre's PhD is funded by a Ligue Nationale contre le Cancer grant. The 'Microsatellite Instability and Cancer' laboratory is supported by the French Ligue Nationale contre le Cancer. 


\section{Conflicts of Interest}

PR Benusiglio: Astra Zeneca (honoraria), Janssen (honoraria), Roche (honoraria), GENETICANCER (patient association, scientific committee member). A Duval: Ligue Nationale contre le Cancer, Fondation pour la Recherche Médicale (scientific committee member). 


\section{REFERENCES}

1. Syngal S, Brand RE, Church JM, et al. ACG clinical guideline: Genetic testing and management of hereditary gastrointestinal cancer syndromes. Am J Gastroenterol. 2015;110(2):223-62; quiz 263. doi:10.1038/ajg.2014.435

2. Crosbie EJ, Ryan NAJ, Arends MJ, et al. The Manchester International Consensus Group recommendations for the management of gynecological cancers in Lynch syndrome. Genet Med. 2019;21(10):2390-2400. doi:10.1038/s41436-019-0489-y

3. Adar T, Rodgers LH, Shannon KM, et al. Universal screening of both endometrial and colon cancers increases the detection of Lynch syndrome. Cancer. 2018;124(15):31453153. doi:10.1002/cncr.31534

4. Ryan NAJ, Glaire MA, Blake D, Cabrera-Dandy M, Evans DG, Crosbie EJ. The proportion of endometrial cancers associated with Lynch syndrome: a systematic review of the literature and meta-analysis. Genet Med. 2019;21(10):2167-2180. doi:10.1038/s41436-019-0536-8

5. Mensenkamp AR, Vogelaar IP, van Zelst-Stams WAG, et al. Somatic Mutations in MLH1 and MSH2 Are a Frequent Cause of Mismatch-Repair Deficiency in Lynch Syndrome-Like Tumors. Gastroenterology. 2014;146(3):643-646.e8. doi:10.1053/J.GASTRO.2013.12.002

6. Monahan KJ, Bradshaw N, Dolwani S, et al. Guidelines for the management of hereditary colorectal cancer from the British Society of Gastroenterology (BSG)/Association of Coloproctology of Great Britain and Ireland (ACPGBI)/United Kingdom Cancer Genetics Group (UKCGG). Gut. 2019:gutjnl-2019-319915. doi:10.1136/gutjnl-2019-319915

7. Rodríguez-Soler M, Pérez-Carbonell L, Guarinos C, et al. Risk of Cancer in Cases of Suspected Lynch Syndrome Without Germline Mutation. Gastroenterology. 2013;144(5):926-932.e1. doi:10.1053/J.GASTRO.2013.01.044

8. Kastrinos F, Uno H, Ukaegbu C, et al. Development and Validation of the PREMM 5 Model for Comprehensive Risk Assessment of Lynch Syndrome. J Clin Oncol. 2017;35(19):2165-2172. doi:10.1200/JCO.2016.69.6120

9. Dominguez-Valentin M, Sampson JR, Seppälä TT, et al. Cancer risks by gene, age, and gender in 6350 carriers of pathogenic mismatch repair variants: findings from the Prospective Lynch Syndrome Database. Genet Med. January 2019. doi:10.1038/s41436-019-0596-9

10. Jiang W, Cai M-Y, Li S-Y, et al. Universal screening for Lynch syndrome in a large 
consecutive cohort of Chinese colorectal cancer patients: High prevalence and unique molecular features. Int J Cancer. 2019;144(9):2161-2168. doi:10.1002/ijc.32044 